\title{
Evaluating the application ability of membrane-less microbial fuel cells in shrimp farming wastewater recirculation
}

\author{
Huong Q. Vo ${ }^{1}$, Ngoc Pham ${ }^{2}$, Hoa T. Pham ${ }^{1}{ }^{*}$
}

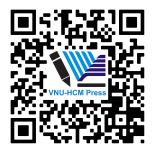

Use your smartphone to scan this QR code and download this article

${ }^{1}$ School of Biotechnology, International University - VNU-HCM, Vietnam

${ }^{2}$ Department of Civil Engineering, International University - VNU-HCM, Vietnam

\section{Correspondence}

Hoa T. Pham, School of Biotechnology, International University - VNU-HCM, Vietnam

Email: pthoa@hcmiu.edu.vn

History

- Received: 25-4-2021

- Accepted: 14-6-2021

- Published: 23-6-2021

DOI : 10.32508/stdjsee.v5i1.556

\section{Check for updates}

\section{Copyright}

(c) VNU-HCM Press. This is an openaccess article distributed under the terms of the Creative Commons Attribution 4.0 International license.

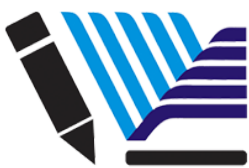

VNU-HCM Press

\begin{abstract}
Microbial fuel cell (MFC) was considerable as a promising saline wastewater treatment which using microorganism to convert organic compounds to electrical energy. Most of wastewater generated from aquaculture farming contained highly saline effluents. In addition, the maintenance of good water quality was essential for optimum growth and survival of shrimp. This study aimed to evaluate the ability of Membrane-less Microbial Fuel Cells (MFCs) to treat wastewater for recirculation of shrimp culture wastewater, and improvement in the growth performance of Penaeus vannamei (White Leg Shrimp). Six MFCs models were built with locally available materials such as: polyvinyl chloride (PVC), anaerobic sludge, carbon cloth anode and cathode electrodes, granular graphite, glass wool and glass bead. This study compared two different treatments including: control (cultivation with no MFCs models) and MFCs models (application models with shrimp culture), run in continuous mode at room temperature $\left(25^{\circ} \mathrm{C}-30^{\circ} \mathrm{C}\right)$. Each treatment was run in triplicate with shrimp at size $\mathrm{PL}_{30}-\mathrm{PL}_{45}$, average initial weight of $0.91 \pm 0(\mathrm{~g})$ and average initial length of 3.03 $\pm 0.6(\mathrm{~cm})$. Experiments were set up using the $120 \mathrm{~L}$ tanks (working volume of $90 \mathrm{~L}$ ), input with seawater at 20 ppt salinity, temperatures range of $22^{\circ} \mathrm{C}$ to $26^{\circ} \mathrm{C}, \mathrm{pH}$ range of 7.5 to 9.4 , and dissolve oxygen range of 5.5 to 7.2 . The density of shrimp was 5 post larvae (PL) per liter. Research results achieved the removal of chemical oxygen demand, ammonia, nitrite and nitrate were up to $58.83 \%, 76.1 \%, 56.33 \%$ and $70.90 \%$, respectively. The survival rate of shrimp was maintained, and growth rate was enhanced significantly compared with control treatment. The obtained results in this study presented that MFCs has ability to treat pre-circulation of shrimp culture wastewater and improved in the growth performance of Penaeus vannamei (White Leg Shrimp).
\end{abstract}

Key words: Membrane-less Microbial Fuel Cells, Wastewater treatment, Electric potential, Recirculation system, Shrimp aquaculture, Penaeus vannamei

\section{INTRODUCTION}

Vietnam is one of the largest shrimp exporters in the world $^{1}$. According to a review published by FAO, Vietnamese shrimp exports increased by $7 \%$ in 2018 compared with 2017. Compared with 2017, official exports from Viet Nam to China increased by $300 \%$ to 14000 tones in 2018. Along with growth rates in output, water pollution, especially the agglomeration of toxic in culture systems will greatly affect the physiological, biochemical functions and diseases of aquatic animals, including whiteleg shrimp. Most farms suffered from disease outbreaks during 20132016 in Viet Nam; some events were not controllable and caused total loss of stock ${ }^{2}$. Therefore, finding solutions to control water parameters during shrimp farming is essential and urgent to limit risks from pathogens, reduce economic losses and help shrimp farming develop sustainably.

Shrimp farming has raised concerns about water pollution of the surrounding environment ${ }^{3}$. The wastewater from shrimp farming usually high in nutrients and chemicals which can pollute the water bodies. Aquaculture wastewater has many characteristics such as: containing large amounts of organic matter, $\mathrm{N}$, and $\mathrm{P}$ due to residues of livestock feed and waste. At the same time, wastewater from aquaculture is also contain pathogenic microorganisms through intensive farming processes, especially high-density intensive farming, and the use of untreated raw surface water. Previous studies reveal that because of unplanned shrimp farming development in many provinces in Vietnam, the surrounding waters have been polluted by wastewater from shrimp farmsc ${ }^{4}$. The nutrient loading of the environment comprises of the unconsumed food and fecal waste, which may cause eutrophication leading to dissolve oxygen depletion ${ }^{5,6}$. The decomposition of organic matter may produce ammonia (in form of unionized ammonia $\mathrm{NH}_{3}$ and ammonium ion $\mathrm{NH}_{4}$ ) and nitrite $\left(\mathrm{NO}_{2}\right)$. Concentration of these compounds increases with a higher loading rate of organic matter ${ }^{7}$. 
While $\mathrm{NH}_{4}$ was not harmful to shrimp, $\mathrm{NH}_{3}$ and $\mathrm{NO}_{2}$ were toxic to them. $\mathrm{NH}_{3}$ levels increased at higher $\mathrm{pH}$ and temperature. Lethal concentration of $\mathrm{NH}_{3}$ $\mathrm{N}$ ranged from 0.5 to $2.0 \mathrm{mg} / \mathrm{L}$ depending on species' tolerance ${ }^{8}$. In short, wastewater contained high level in nutrients were dangerous for shrimp and shrimp farming, directly cause of stress, poor appetite, growth reduction, susceptibility to bacterial and mass killing. In major parts of the world, currently practicing wastewater treatment methods were designed in relation with the conventional activated sludge process ${ }^{9}$. This type of waste treatment had wasted the valuable energy stored in the organic compounds contained in waste. Moreover, the production of electricity from waste and renewable biomass using microbes has gained much attention recently. One of the models that has been found to have potential for wastewater treatment and produce electricity was microbial fuel cells (MFCs). MFCs were the promising devices that treat wastewater using microbes as biocatalysts and produce electricity by anaerobic fermentation of organic and inorganic matter ${ }^{9}$. MFC represented a promising candidate as a new method due to its combination effectiveness in wastewater treatment, electricity generation, and low cost as in comparison with other methods of wastewater treatment ${ }^{10}$. MFC was a device that directly convert energy stored in chemical bonds of the substrates to electrical energy through catalytic reactions of microorganisms ${ }^{11,12}$. The reaction occurs at the two compartments of MFC described by ${ }^{13}$

Anode oxidation reaction:

$\left(\mathrm{CH}_{2} \mathrm{O}\right)_{n}+\mathrm{nH}_{2} \mathrm{O} \stackrel{\text { Microorgamisms }}{\longrightarrow} \mathrm{nCO}_{2}+4 \mathrm{ne}^{-}+$ $4 \mathrm{nH}^{+}$

Cathode reduction reaction:

$4 \mathrm{e}^{-}+4 \mathrm{H}^{+}+\mathrm{O}_{2} \rightarrow 2 \mathrm{H}_{2} \mathrm{O}$

Overall reaction:

$\left(\mathrm{CH}_{2} \mathrm{O}\right)_{n}+\mathrm{nO}_{2} \rightarrow \mathrm{nCO}_{2}+\mathrm{nH}_{2} \mathrm{O}+$ Electrical energy Added substrates was oxidized under anaerobic conditions by microbes in the anodic chamber of an MFC and release electrons, protons and carbon dioxide. The electrons were transferred to the anode and transported to the cathode through an external circuit while the protons crossing a proton exchange membranes (PEMs) or a salt bridge to enter the cathodic chamber where they combine with oxygen to form water ${ }^{14}$. The first observation of electrical current generated by bacteria was generally credited to Potter ${ }^{15}$. However, very few practical advances were achieved in this field even 55 years later ${ }^{16}$. In the early 1990s, fuel cells became of more interest and work on MFCs began to increase ${ }^{17}$. Nowadays, MFCs were being constructed using a variety of materials and in an ever-increasing diversity of configuration. However, MFCs have not been extensively studied because of the high cost of the components. Hence, the membrane-less microbial fuel cells (MFCs) gained more and more popularity due to the low cost compared to the MFC with membrane ${ }^{18}$.

In recent years, MFCs were appreciated by many researchers for the impact on many different types of wastewater such as: domestic wastewater, swine wastewater, cow-wastewater and fish wastewater due to their cost effectiveness better than MFCs. In a study on domestic wastewater (246 mg-COD/L) and a flat plate MFC, Min and Logan ${ }^{19}$ achieved 58\% COD removal with a 2 -h hydraulic retention time (HRT), and $79 \%$ removal at a 4 -h HRT. In tests using swine wastewater, it was found $83 \pm 4 \%$ ammonia removal with $86 \pm 6 \%$ soluble COD removal over a 100 -h batch cycle ${ }^{20}$. Nitrate concentrations increased from $3.8 \pm 1.2$ to $7.5 \pm 0.1 \mathrm{mg} \mathrm{NO}-\mathrm{N} / \mathrm{L}$, indicating that nitrification due to oxygen diffusion into the single chamber MFC through the air- cathode. In a study on a cow-waste slurry ${ }^{21}$, they reported $16 \%$ nitrogen removal and $30 \%$ phosphorus removal under conditions where $84 \%$ of the BOD was removed. In our previous unpublished study using MFC, the COD removal was up to $37.69 \%$ and $49.37 \%$ in mixed culture and pure culture treatment, respectively. The MFCs were capable to maintained $\mathrm{pH}$ from 6.5 to 7.5 and turbidity from 5.25 to 13.29 in order to reach from $71.7 \%$ to $100 \%$ survival rate of fish. In brief, these studies and data have shown that MFCs were a good candidate for wastewater treatment.

In the field of aquaculture, there was limited research on MFC, especially under high salinity conditions. So, this research will provide initial information in this field. In this study, Penaeus vannamei (White leg Shrimp) with seawater $20 \mathrm{ppt}$ were used to evaluate the effectiveness of using MFC in wastewater treatment for indoor recirculation system raising white leg shrimp Penaeus vannamei. This study designed membrane-less microbial fuel cell (MFCs) for evaluating the effectiveness of MFCs in shrimp farming, including evaluating the capacity for wastewater treatment, power production at optimum resistance along with enhancing of growth rate of shrimp. This study aimed at exploiting the application potential in for the highly effective white leg shrimp farming.

\section{MATERIALS AND METHODS}

\section{Experimental setup of Membrane-less Mi- crobial Fuel Cells}

Microbial Fuel Cells was constructed according to the design of ${ }^{22}$ with minor modification using easily available materials to reduce cost. Each cell was 
constructed by using Polyvinyl Chloride (PVC) pipe. Electrodes were round shape carbon cloth which 10 $\mathrm{cm}$ in diameter and $5 \mathrm{~mm}$ in thick in the middle two stainless steel mesh at two sides. These components of the electrode were connected together by the nut and bolt which connects to the copper wire in the top of the bolt. The disk-shaped anode located $25 \mathrm{~cm}$ from the bottom of the cell and the cathode at the top, separated by $30 \mathrm{~cm}$ layers of glass wool and glass beads. Electrode are filled with granular graphite. The aeration was located just below the cathode chamber to create the aerobic environment. The port for sludge injection is $27 \mathrm{~cm}$ from the bottom, just above the electrode. Gravel was put at the bottom and the top of each cell to prevent the movement of the cell. Anode and cathode were connected by copper wire and connected to the resistor $(1000 \mathrm{Ohm})$ in order to consume the electricity generation continuously. Six membrane-less Microbial Fuel Cells (MFCs) models were setup, with two models used for one shrimp tank, and triplicated for each treatment. The $250 \mathrm{~mL}$ anaerobic sludge collected from wastewater treatment plant in Ho Chi Minh City was injected to the anodic zone. The voltage of MFCs was measured continuously by Arduino Mega 2560 R3 Road. MFCs models was run with artificial wastewater at least 2 weeks before start up the experiments.

\section{Culturing shrimp for the experiment}

To obtain shrimps for the MFC experiment, shrimp stock was raised in the culture tanks to reach size $\mathrm{PL}_{30}$ before starting the experiments. The culture tanks were designed using the $750 \mathrm{~L}$ composite tanks. Before starting the experiments, all tanks were cleaned carefully with water, then sun dried, and keep in a dry place until use. Seawater (at $20 \mathrm{ppt}$ ) was bought from Vung Tau province. Seawater was treated by Povidone $10 \%$ at concentration $0.25 \mathrm{mg} / \mathrm{L}$ for sterilization. The tanks were aerated continuously in 2-3 days to evaporate all chemical-waste residues before starting the shrimp cultivation.

Penaeus vannamei (White Leg Shrimp) broodstock, postlarvae 10-day old $\left(\mathrm{PL}_{10}\right)$ were purchased from Gold Key Company in Ca Mau Province which was free of any pathogens. Postlarvae were raised in two 750 -L hatchery tanks filled with $500-\mathrm{L}$ seawater $20 \mathrm{ppt}$ at a stocking density of 5 PL per liter. Postlarvae were fed three times a day (8:30 AM, 12:00 PM and 15:30 $\mathrm{PM}$ ) with commercial feed (Skretting product) suitable for different stages of life. Feeding regime followed instruction of manufacturing company. When the postlarvae reached $\mathrm{PL}_{30}$, then shrimp was collected to input to the MFC experiments
MFCs models applied to the shrimp culture

In this study, two treatments were performed, including (i) control (no MFCs) and (ii) MFCs (Application MFCs models in shrimp culture). The shrimp tanks were the $120 \mathrm{~L}$ glass tanks filled with $90 \mathrm{~L}$ of chlorinated seawater 20 ppt. Each shrimp tank attached with two MFC connected in parallel (Figure 1). The couples were name MFCs 1-4, MFCs 2-5 and MFCs 3-6 for each shrimp tank, respectively. The post larvae shrimp after reach $\mathrm{PL}_{30}$ were taken from the culture tanks (from section Culturing shrimp for the experiment) and added to the experiment tanks. The stocking density of shrimp was 1 PL per litter. Aeration was given to the entire culture period for all tanks. Aeration was made using air pumping. Aeration speed was adjusted manually to reach DO > $4 \mathrm{ppm}$. Totally 12 aerators were fixed for all culture tanks and the MFCs models. In the circulating system with MFCs models, shrimp wastewater was pumped to the anode of MFCs by submerged pumps at velocity $19 \mathrm{~mL} / \mathrm{min}$. The effluent coming out from cathodes were discharged back to the shrimp tanks. The circulating systems were operated for 15 days, continuously. Shrimp was fed three times a day (at 8:30 AM, 12:00 PM and 15:30 PM) with commercial feed suitable for different stages of life. During this time, water quality, weight gain and survival were all evaluated. All samples were collected in falcon $50 \mathrm{~mL}$ at $14 \mathrm{pm}$ $15 \mathrm{pm}$ and stored at $4^{\circ} \mathrm{C}$ until analysis (within 1 day).

\section{Analysis \\ Voltage generation from MFC}

In this study, electricity voltage generated from the MFC was measured continuously using the Arduino mega 2560 R3 board connected to Arduino Data Logging Shield which was adopted to measure the voltage of the MFCs. The data was stores in the SD card 8GB in real-time using Arduino SD Shield with a build-in real-time clock once an hour continuously. At the end of experiment, output data was input to computer for analyses.

\section{Determination of parameters of shrimp cul- ture}

The water quality parameters including salinity, $\mathrm{pH}$, temperature and dissolved oxygen were measured by using hand refractometer and YSI Professional Plus Instrument (Pro Plus), respectively. The growth parameters were calculated following the method described by (Bagenal, 1978) as follows below:

Averge Daily Weight Gain $(\mathrm{ADW})=$ (Final weightInitial weight)/(Days) 


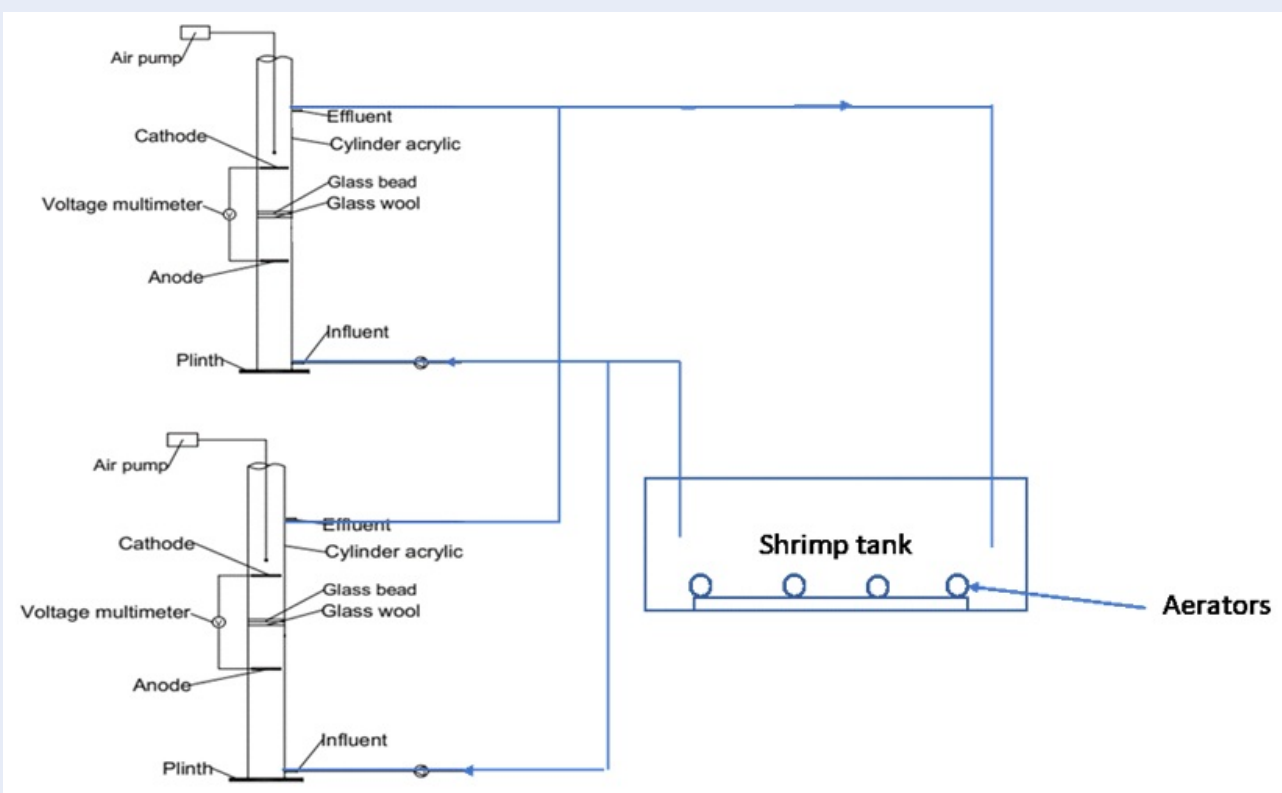

Figure 1: Schematic representation of the MFC installed with the shrimp tank

Averge Daily Length Gain $(\mathrm{ADL})=$ (Final lengthInnitial Length)/(Days)

Survial rate $(\mathrm{SR})=$ (Final No.of animal survival (shrimp) $) \mathrm{x} 100 /(\mathrm{t}$ (days))

Feed Conversion Rate $($ FCR $)=($ Feed given $) /($ Animal weight gain)

\section{Determination of water quality parameters}

Water samples collected at each time interval were filtered and analyzed immediately. Otherwise, the filtered water samples were stored at $5^{\circ} \mathrm{C}$ and analyzed within 3 days. Four parameters for water quality including Chemical oxygen demand (COD), Nitrite $\left(\mathrm{NO}_{2}\right)$, Nitrate $\left(\mathrm{NO}_{3}\right)$ and Ammonia $\left(\mathrm{NH}_{3}\right)$ were monitored at days $0,2,5,8,12$ and 15. COD, Nitrite$\mathrm{N}$, Nitrate-N and Phosphate were measured according to the standard methods (TCVN 6491: 1999 (ISO 6060: 1989), TCVN 6178: 1996 (ISO 6777: 1984 (E), TCVN 6180: 1996 (ISO 7890/3: 1988 (E)) and TCVN 6202: 2008 (ISO 6878: 2004)).

\section{Statistical analysis}

The collected data were calculated the mean, standard deviation and percentage using Excel software of Office 2010. One - way ANOVA (Analysis of variance) running by the SPSS version 16 system was used to analyze the results of the chemical oxygen demand, nitrite, nitrate and ammonia. Then, Duncan's test with significance level at $\mathrm{p}<0.05$ was used to compare the means of the results.

\section{RESULT \& DISCUSSION}

\section{Electricity generation}

In this study, there were two MFCs attached with each shrimp tank. The couples attached to each shrimp tank was named as MFCs 1-4, MFCs 2-5 and MFCs $3-6$, respectively. The results on the voltage generation from each individual MFC showed in Figure 2 reveal similar trend during 15 days. There were considerable fluctuations in voltage between the six MFCs and between days, with lowest value at day 10 of MFCs $4(0.021 \mathrm{~V})$ models and highest at day 15 for MFC 1 and $3(0.488 \mathrm{~V})$. MFCs 4 and 6 had approximately the same voltage rate which increasing to $0.188 \mathrm{~V}$ in day 14 and then plunged to a low value $0.076 \mathrm{~V}$ in day 15 . Over 2 weeks of the experiment, the MFCs 1, 2 and 3 systems had higher voltage than the MFCs 4, 5 and 6 (Figure 2).

Figure 3 displayed the average value of voltage taken for each couple MFCs (attached to each shrimp tank). Similar trend of voltage data obtained for the three couple models at which voltage peaks at day 0 , day 6 and day 14. However, the average voltage of MFCs 3-6 was two times higher than that of MFCs 1-4 and MFCs 2-5. While both MFCs 1-3 and MFCs 2-5 reached about $0.234 \mathrm{~V}, 0.258 \mathrm{~V}$ and $0.272 \mathrm{~V}$ of average voltage, MFCs 3-6 reaching a peak of $0.371 \mathrm{~V}, 0.419 \mathrm{~V}$ and $0.564 \mathrm{~V}$ at day 2, day 6 and day 14, respectively. The fluctuation of voltage between the MFCs could be linked with the variation between the shrimp tanks. 


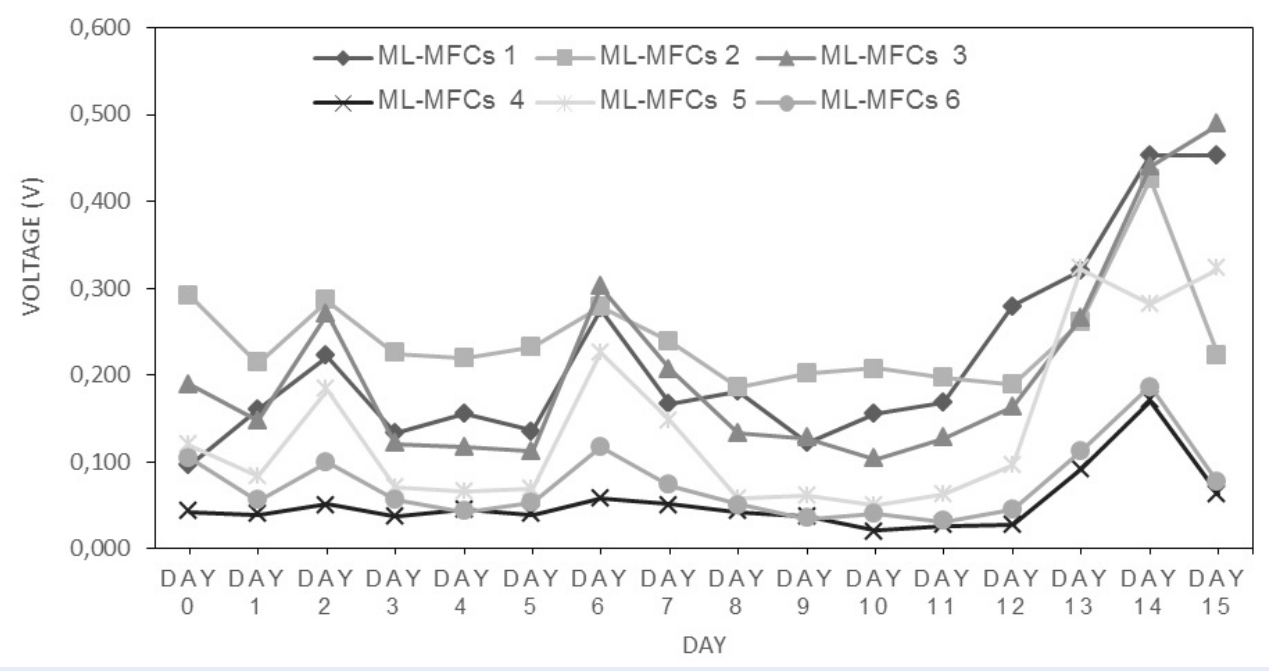

Figure 2: Voltage (V) generation from each MFCs model operated continuously for 15 days.

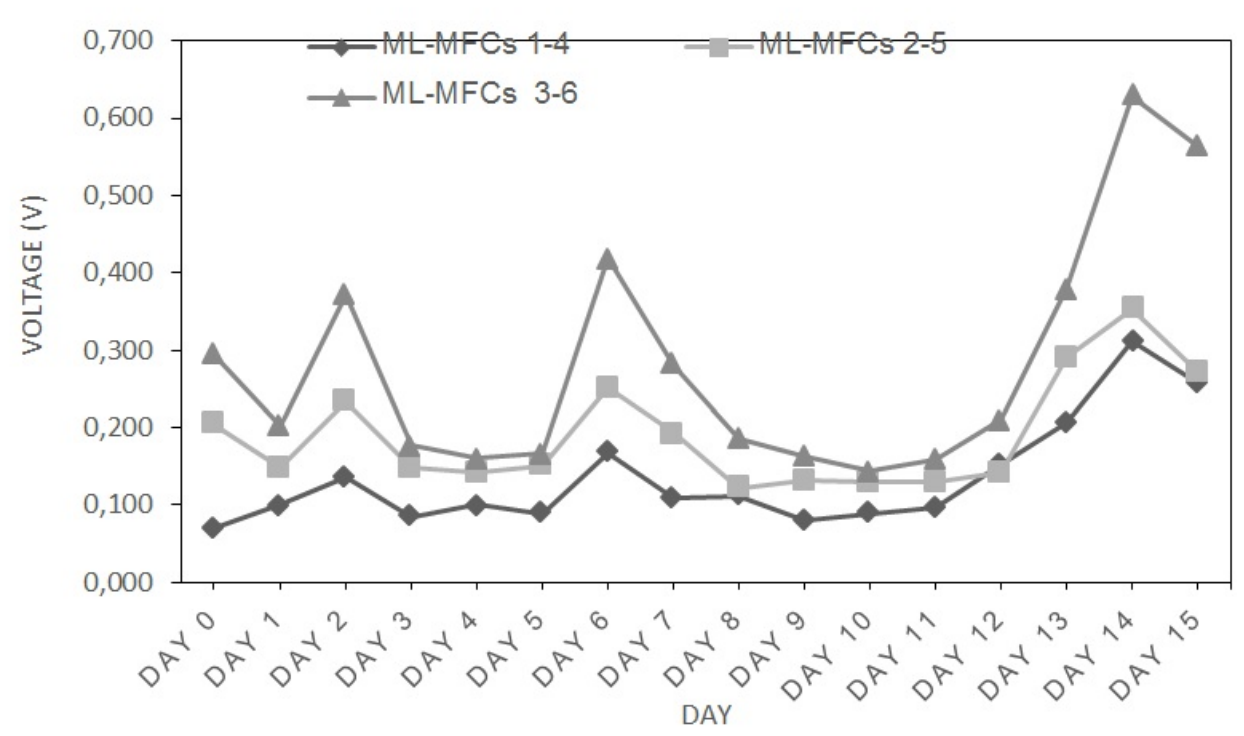

Figure 3: Voltage (V) generation from each couple MFCs attached to each shrimp tank operated continuously for 15 days MFCs 1-4, MFCs 2-5 and MFCs 3-6 was attached to shrimp tank 1, 2 and 3, respectively.

The input water to each MFC come from the separated shrimp tank. Each shrimp tank could vary in food residue, which could influence water quality in each tank. COD in the shrimp tanks at a time internal varied with standard deviation in range of 1.8 to $3.7 \mathrm{mg}$ COD/L (data in section Chemical Oxygen Demand removal efficiency). This could make the variation in electricity generation in the MFCs couples.

\section{Chemical Oxygen Demand removal effi- ciency}

Results of chemical oxygen demand (COD) in the control tank, shrimp tank and MFC output were showed in Figure 4. As a general trend, there was a linear growth in COD of the water in the control, the shrimp tank and outflow of MFCs after 16 days. COD of outflow collected at the MFCs models after 16 days ranged from 12.8 to $42.67 \mathrm{mg} \mathrm{O}_{2} / \mathrm{L}$, which was lower 


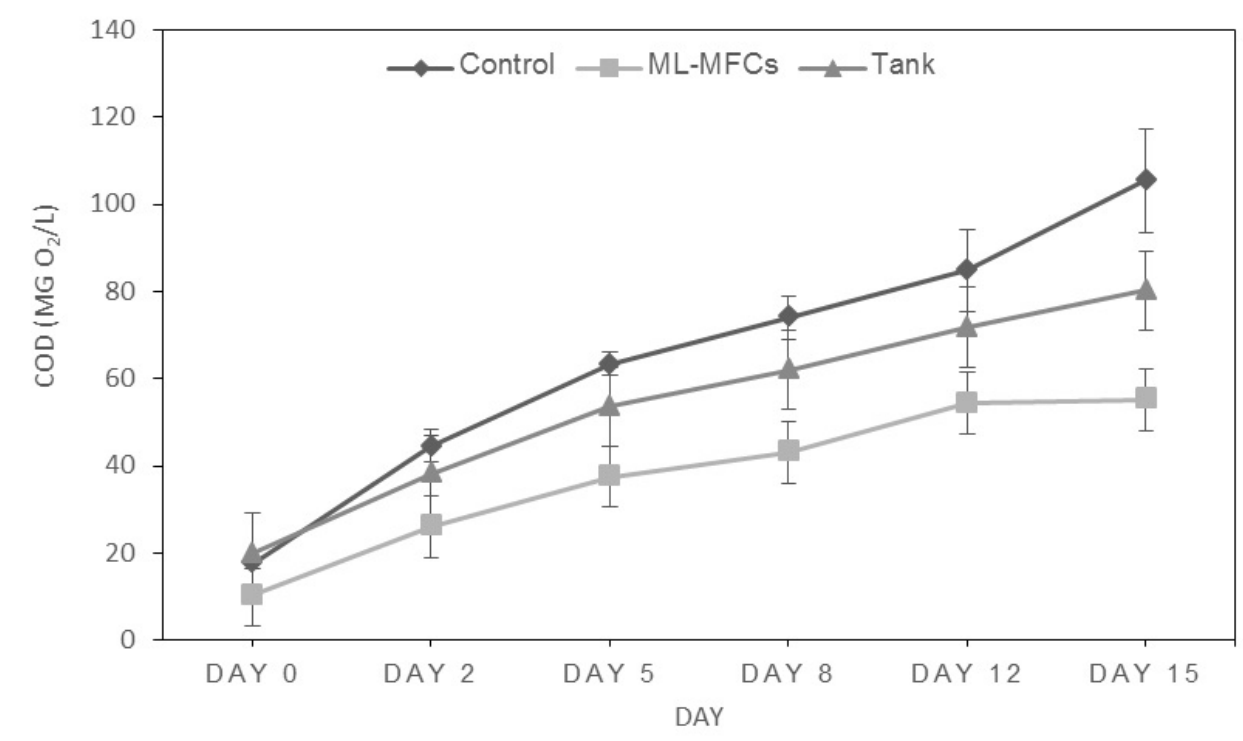

Figure 4: The line graph compared Chemical Oxygen Demand (COD) values (mgO2/L) including: (i) blue: control tank, (ii) orange: MFCs model (outflow water) and (iii) green: shrimp tanks applied MFCs. Vertical bars showed standard deviation each data point. $\mathrm{mg}$

than water in the shrimp tank (COD from 36.27 to $72.53 \mathrm{mg} \mathrm{O}_{2} / \mathrm{L}$ ) and the control (COD from 40.53 to $89.60 \mathrm{mg} \mathrm{O}_{2} / \mathrm{L}$ ). The COD removal by MFCs was up to $35.29 \%$ and $58.83 \%$ run in continuous shrimp feeding mode. This finding was consistent with the work of our previous work (published data in progress) observed a proportionate treatment high percentage in COD of prawn farming water collected from $37.69 \%$ to $49.37 \%$. This result verified the efficiency of MFC operate in the continuous mode of wastewater treatment. Previous research reported the efficiency of MFCs in wastewater treatment, but mostly at small scale operated in the batch mode ${ }^{10}$.

\section{Ammonia removal efficiency}

Ammonia can be generated from the decomposing of organic matter in aquaculture tank. Ammonia is closely related to $\mathrm{pH}$ and temperature. The toxicity of ammonia is higher at low temperature, low dissolved oxygen and low $\mathrm{pH}$. The results of this experiment showed in Figure 5 provided that the $\mathrm{NH}_{3}-\mathrm{N}$ concentration in MFCs model and shrimp tanks applied MFCs increasing at a similar rate while the amount of $\mathrm{NH}_{3}-\mathrm{N}$ concentration in the control tank were always the highest. On Day 0 , there were absence of $\mathrm{NH}_{3}-\mathrm{N}$ in all treatments, but on day 2 the amount of $\mathrm{NH}_{3}-\mathrm{N}$ concentration increased with time. $\mathrm{NO}_{2}-\mathrm{N}$ concentration in MFCs models and the MFC shrimp tanks rose gradually compared to the more rapidly increased in the control tank (which rose from about $0.050 \mathrm{mg} / \mathrm{L}$ in Day 2 to about $0,310 \mathrm{mg} / \mathrm{L}$ in Day 8). By Day 15 there was $0.90 \mathrm{mg} / \mathrm{L}, 0.4 \mathrm{mg} / \mathrm{L}$ and $0.5 \mathrm{mg} / \mathrm{L}$ in control tanks, MFCs models and MFC shrimp tanks, respectively. The amount of $\mathrm{NH}_{3}-\mathrm{N}$ was highest in the control tank. The $\mathrm{NH}_{3}-\mathrm{N}$ removal efficiency of the MFCs models reached $44 \%$ in this study which run under continuous mode. The statistical analysis showed that there was a significant difference in $\mathrm{NO}_{2}$ $\mathrm{N}$ concentration between control tank, MFCs models and MFC shrimp tanks. This result was lower than the efficiency obtained from the Min et al (Min et al., 2005), which achieved $83 \%$ of ammonia removal for the swine wastewater. This different can come from some difference between the two studies. This study work on salty water at low concentration of organic matter and ammonia, which could create lower efficiency of COD and nitrogen related compounds removal.

\section{Nitrite efficiency}

The effect of nitrite on shrimp is highly dependent on the salinity of water. In water with high salinity, there are many $\mathrm{Cl}^{-}$ions that will compete and limit the effects of nitrite. The higher the salinity, the lower the toxicity of the nitrite. The Figure 6 showed the appreciation increasing of $\mathrm{NO}_{2}-\mathrm{N}$ concentration in 


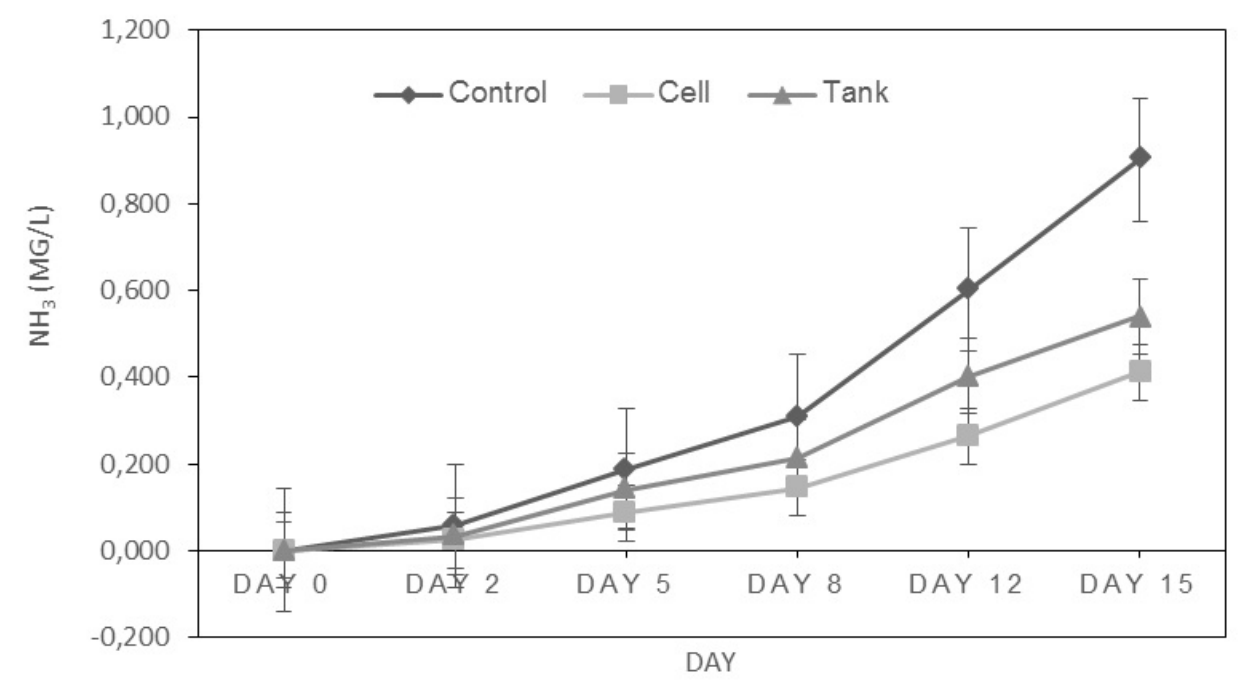

Figure 5: The line graph compared NH3-N concentration (mg/L) including: (i) blue: control tank, (ii) orange: MFCs model (output water) and (iii) green: tank was applied MFCs (input water) for 16 days.

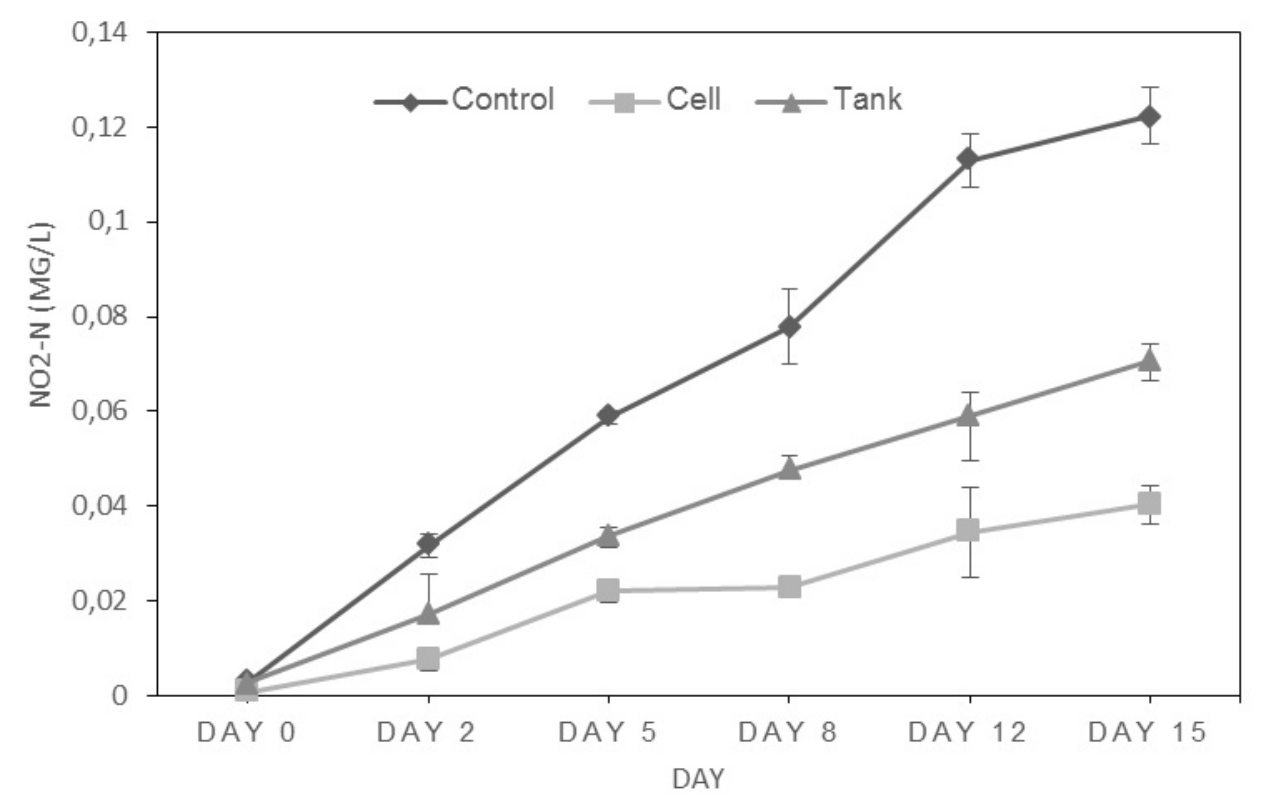

Figure 6: The line graph compared NO2-N concentration (mg/L) including: (i) blue: control tank, (ii) orange: MFCs model (output water) and (iii) green: tank was application MFCs (input water). Vertical bars were the standard deviation at each data point. 
control tank, MFCs and tank with MFCs within 15 days. The amount of $\mathrm{NO}_{2}-\mathrm{N}$ concentration in MFCs and shrimp tanks with MFCs increased at a similar rate while the $\mathrm{NO}_{2}-\mathrm{N}$ concentration in the control tank were always the highest. On Day 0, there were no $\mathrm{NO}_{2}-\mathrm{N}$ in all treatments, but on day 2 the amount of $\mathrm{NO}_{2}-\mathrm{N}$ concentration rose to at least $0.010 \mathrm{mg} / \mathrm{L}$ for the MFCs outflow. The $\mathrm{NO}_{2}-\mathrm{N}$ concentration in control tank rose to the range $0.020 \mathrm{mg} / \mathrm{L}$ to 0.030 $\mathrm{mg} / \mathrm{L}$. Over the next few days $\mathrm{NO}_{2}-\mathrm{N}$ concentration in MFCs model and tank with MFCs rose gradually while the amount of $\mathrm{NO}_{2}-\mathrm{N}$ concentration in the control tank rose significantly from about $0.030 \mathrm{mg} / \mathrm{L}$ in Day 2 to about $0,080 \mathrm{mg} / \mathrm{L}$ in Day 8. By Day 15 there was $0.020 \mathrm{mg} / \mathrm{L}$ in MFCs model, $0.060 \mathrm{mg} / \mathrm{L}$ in shrimp tanks applied MFCs and $0.120 \mathrm{mg} / \mathrm{L}$ in control tank. The $\mathrm{NO}_{2}-\mathrm{N}$ in the two other was increasing a very slightly amount day by day must less than the amount the increasing in the control tank. The $\mathrm{NO}_{2}-\mathrm{N}$ removal efficiency of MFCs was in range from 33.33\% to $56.33 \%$. The statistical analysis showed that there was a significant difference in $\mathrm{NO}_{2}-\mathrm{N}$ concentration between control tank, MFCs models and MFCs tanks $(\mathrm{p}<0.05)$.

\section{Nitrate removal efficiency}

There are very few information and study about impact of $\mathrm{NO}_{3}$ on shrimp culture. Previous studies have typically been performed at $\mathrm{NO}_{3}$ levels that were considered safe for shrimp. Some recommendations indicate that $\mathrm{NO}_{3}-\mathrm{N}$ levels should be maintained below $100 \mathrm{mg} / \mathrm{L}$. Data in Figure 7 showed a linear considerable growth in $\mathrm{NO}_{3}-\mathrm{N}$ concentration in shrimp farming water after 16 days under both control and MFCs treatment. $\mathrm{NO}_{3}-\mathrm{N}$ concentration at the outflow of the MFCs models after 16 days ranged from 7.48 to 49.81 $\mathrm{mg} / \mathrm{L}$, which was lower than that of samples collected from shrimp tanks (from 13.75 to $70.25 \mathrm{mg} / \mathrm{L}$ ) and from the control tanks (from 14.97 to $105.36 \mathrm{mg} / \mathrm{L}$ ). The $\mathrm{NO}_{3}-\mathrm{N}$ concentration removal was up to $54.40 \%$ and $70.90 \%$. The statistical analysis showed that there was a significant difference in $\mathrm{NO}_{3}-\mathrm{N}$ concentrations between the treatments $(\mathrm{p}<0.05)$. Figures 5 and 6 and Figure 7 showed the coherence between ammonia, $\mathrm{NO}_{2}-\mathrm{N}$, and $\mathrm{NO}_{3}-\mathrm{N}$ generation in all treatments along the cultivation period of shrimp. Those results suggested that nitrogen in all three forms were utilized in the MFC during the metabolism process. However, the removal efficiency of nitrogen could be influent by other factor, such as salinity and the strength of organic matter in waste, such as the study of ${ }^{20}$.

\section{Shrimp culture efficiency}

Water quality parameters

Water quality of the culture tanks were summarized in Table 1. Three parameter including $\mathrm{pH}$, temperature and DO were measured two times per day (at $9 \mathrm{AM}$ and $15 \mathrm{PM}$ ) corresponding the feeding regime of shrimp. $\mathrm{pH}$ of the six culture tanks was fluctuated between 7.5 and 8.8 in the morning, while in range between 8.1 and 9.4 in the afternoon. DO was fluctuated between $5.5 \mathrm{mg} / \mathrm{l}$ to $6.5 \mathrm{mg} / \mathrm{l}$ in the morning and between $5.3 \mathrm{mg} / \mathrm{l}$ to $7.2 \mathrm{mg} / \mathrm{l}$ in the evening. In general, the morning measurements was lower as the crop standing after night time. Average morning and afternoon pond temperatures were $22^{\circ} \mathrm{C}$ to $26^{\circ} \mathrm{C}$, respectively. In general, the temperature trend through the production cycle started with temperatures around $26^{\circ} \mathrm{C}$ in the afternoon dropped to $22{ }^{\circ} \mathrm{C}$ in the morning and evening because of an air-conditioner always open during the process of shrimp culture. During the culture period the maximum salinity was recorded $21.3 \mathrm{ppt}$ and minimum salinity was recorded $20.1 \mathrm{ppt}$ in all the ponds.

\section{Growth rate}

The cultivation period tested in this study was 16 days at the most sensitive size of post larvae. After 16th days of shrimp culture, the growth in length of White leg shrimp was described below (Table 2). The average final length of the shrimp at harvest were $4.60 \pm$ 0.52 and $4.96 \pm 0.42$; Average-daily length (ADL) gain were $0.1 \pm 0.01$ and $0.1 \pm 0.01$; Specific growth rate (SGR) were $2.6 \pm 0.21$ and $3.1 \pm 0.18$ for control tank and MFCs tank, respectively.

Parameters related to the growth in weight was recorded in Table 3. The average final weight of the shrimp at harvest were $3.12 \pm 0.13$ and $3.97 \pm 0.21$; Average-daily weight gain were $0.14 \pm 0.01$ and 0.19 \pm 0.01 ; Specific growth rate were $7.7 \pm 0.27$ and $9.2 \pm$ 0.32 ; FCR were $0.18 \pm 0.01$ and $0.13 \pm 0.01$; survivals were $84.58 \pm 0.72$ and $92.92 \pm 0.72$ for control tank and MFCs tank, respectively.

\section{CONCLUSION}

The obtained results in this study presented that MFCs has ability to treat pre-circulation of shrimp culture wastewater and improved in the growth performance of Penaeus vannamei (White Leg Shrimp). The maintenance of good water quality was essential for optimum growth and survival of shrimp. Good water quality characterized by adequate dissolved oxygen, temperature, $\mathrm{pH}$ and salinity. Excess 


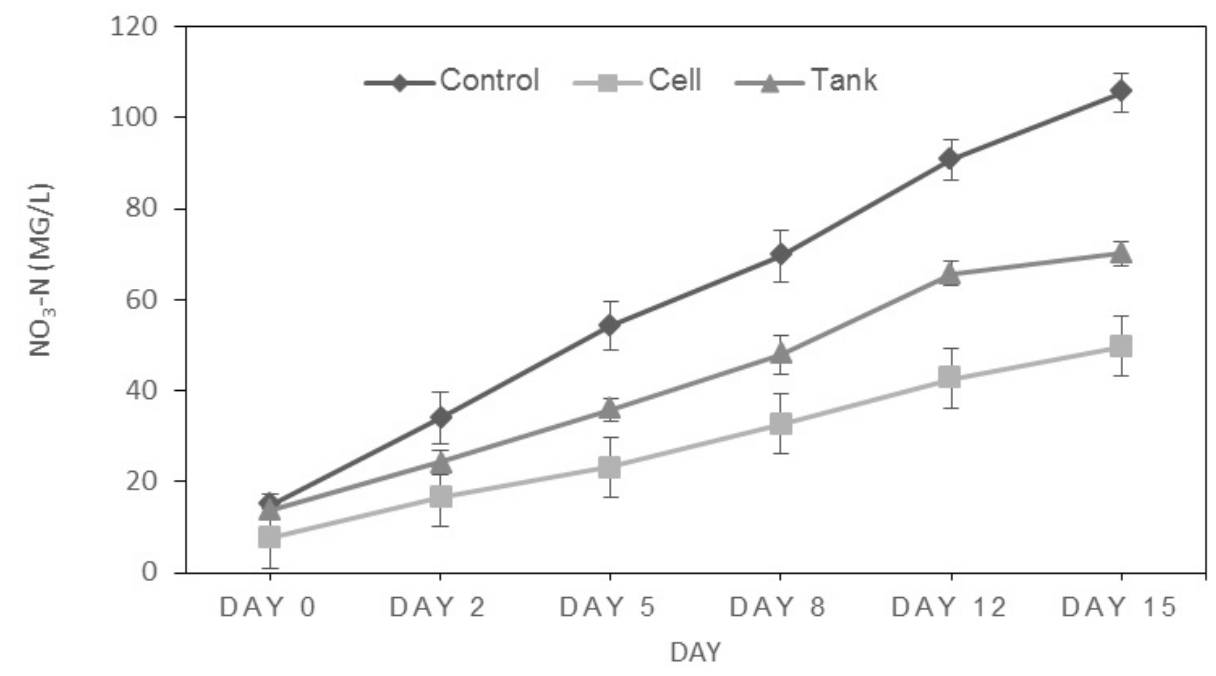

Figure 7: NO3-N concentration (mg/L) in all treatments, including: (i) blue line: control tank, (ii) orange line: MFCs model (output water) and (iii) green: shrimp tank with MFCs. Vertical bars were the standard deviation at each data point.

Table 1: Water parameters range of White leg shrimp culture for 16 days for both control tanks and MFCs shrimp tanks. Data showed in this table was the average values of the triplicates for each treatment.

\begin{tabular}{ll} 
Parameters & Range \\
Salinity (ppt) & $20.1-21.3$ \\
Temperature (oC) & $22-26$ \\
pH (Morning) & $7.5-8.8$ \\
pH (Afternoon) & $8.1-9.4$ \\
Dissolve oxygen (Morning) & $5.5-6.5$ \\
Dissolved oxygen (Afternoon) & $5.3-7.2$ \\
\hline
\end{tabular}

Table 2: Mean ( \pm SD) final length, average daily length gain (ADL), specific growth rate (SGR) and feed conversion rate (FCR) of White leg shrimp with shocking density was $80 \mathrm{PL} / 80 \mathrm{~L}$ for 16 days including control tank and MFCs tank.

\begin{tabular}{lll}
\hline & Control tank & MFCs tank \\
Stocking density (number/L) & $80 / 80 \mathrm{~L}$ & $80 / 80 \mathrm{~L}$ \\
Growth period (days) & 16 & 16 \\
Initial length (cm) & $3.03 \pm 0.6$ & $3.03 \pm 0.6$ \\
Final length (cm) & $4.60 \pm 0.52$ & $4.96 \pm 0.42$ \\
ADL (g/day) & $0.1 \pm 0.01$ & $0.1 \pm 0.01$ \\
SGR (\%/day) & $2.6 \pm 0.21$ & $3.1 \pm 0.18$ \\
\hline
\end{tabular}


Table 3: Mean ( \pm SD) final weigh, average daily weight gain (ADW), specific growth rate (SGR), feed conversion rate (FCR) and survival rate (\%) of Whiteleg shrimp with shocking density was $80 \mathrm{PL} / 80 \mathrm{~L}$ for 16 days including control tank and MFCs tank.

\begin{tabular}{lll}
\hline & Control & Experiment \\
Stocking density (number/L) & $80 / 80 \mathrm{~L}$ & $80 / 80 \mathrm{~L}$ \\
Growth period (days) & 16 & 16 \\
Initial weight & $0.91 \pm 0$ & $0.91 \pm 0$ \\
Final weight & $3.12 \pm 0.13$ & $3.97 \pm 0.21$ \\
ADW (g/day) & $0.14 \pm 0.01$ & $0.19 \pm 0.01$ \\
SGR (\%/day) & $7.7 \pm 0.27$ & $9.2 \pm 0.32$ \\
FCR & $0.18 \pm 0.01$ & $0.13 \pm 0.01$ \\
Survival Rate (\%) & $84.58 \pm 0.72$ & $92.92 \pm 0.72$ \\
\hline
\end{tabular}

feed, fecal matter and metabolites will exert tremendous influence on the water quality of the shrimp farming. MFCs models was removal up to $58.83 \%$, $76.1 \%, 56.33 \%$ and $70.90 \%$ of chemical oxygen demand, ammonia, nitrite and nitrate. This paper only investigated one shrimp farming density. Therefore, we recommended that more studies is needed in application of MFCs system with different density of shrimp culture before scale up to practical aquaculture farming.

\section{ACKNOWLEDGEMENTS}

This research is funded by Vietnam National University Ho Chi Minh City (VNU-HCM) under grant number B2019-28-01.

\section{LIST OF ABBREVIATIONS}

ADL: Average-daily length

ADW: Average-daily weigh

BOD: Biological oxygen demand

COD: Chemical oxygen demand

FAO: Food and Agriculture Organization

FCR: Feed conversion rate

HRT: Hydraulic retention time

MFC: Microbial fuel cell

MFCs: Microbial fuel cells

PEMs: Proton exchange membranes

PL: Post larvae

PVC: Polyvinyl chloride

SGR: Specific growth rate

\section{CONFLICT OF INTEREST}

The authors assure that there is no conflict of interest from any other party regarding the content of this paper

\section{AUTHOR'S CONTRIBUTION}

Authors, Vo Que Huong, Pham Ngoc, and Pham Thi Hoa, had jointly conducted this research and wrote this article.

\section{REFERENCES}

1. Lan NTP. Social and ecological challenges of market-oriented shrimp farming in Vietnam. SpringerPlus. 2013;2(1):110;Available from: https://doi.org/10.1186/2193-1801-2-675.

2. Pongthanapanich T, Nguyen KAT, Jolly CM. Risk management practices of small intensive shrimp farmers in the Mekong Delta of Viet Nam. FAO Fisheries and Aquaculture Circular. 2019(C1194):I-20.

3. Trai N, Momtaz S, Zimmerman K. Water pollution concerns in shrimp farming in Vietnam: A case study of Can Gio, Ho Chi Minh City. The International Journal of Environmental Cultural, Economic and Social Sustainability. 2006;3(2):129 38;Available from: https://doi.org/10.18848/1832-2077/CGP/ v03i02/54339.

4. Tuan L. Country case study: Trade in fisheries and human development, Vietnam. Asia-Pacific Regional Initiative on Trade, Economic Governance and Human ...; 2003;

5. Hambrey J, editor The sustainability of shrimp farming. Seminar on aquaculture industry: Prospects and; 1996;

6. Rönnbäck P. Environmentally sustainable shrimp aquaculture. Sweden, Swedish Society. 2002;.

7. Páez-Osuna F. The environmental impact of shrimp aquaculture: causes, effects, and mitigating alternatives. Environmental Management. 2001;28(1):131-40;Available from: https:// doi.org/10.1007/s002670010212.

8. Harrison RM. Pollution: causes, effects and control: Royal society of chemistry; 2001;

9. Bhargavi G, Venu V, Renganathan S, editors. Microbial fuel cells: recent developments in design and materials. IOP Conference Series: Materials Science and Engineering; 2018 : IOP Publishing;Available from: https://doi.org/10.1088/1757899X/330/1/012034.

10. Logan BE. Microbial fuel cells: John Wiley \& Sons; 2008;Available from: https://doi.org/10.1002/9780470258590.

11. Heilmann J, Logan BE. Production of electricity from proteins using a microbial fuel cell. Water Environment Research. 2006;78(5):531-7;Available from: https://doi.org/10. 2175/106143005X73046.

12. Logan $B E$, Regan JM. Electricity-producing bacterial communities in microbial fuel cells. TRENDS in Microbiology. 2006;14(12):512-8;Available from: https://doi.org/10.1016/j tim.2006.10.003. 
13. Chang I-S, Moon H-S, Bretschger O, Jang J-K, Park H-I, Nealson $\mathrm{KH}$, et al. Electrochemically active bacteria $(\mathrm{EAB})$ and mediator-less microbial fuel cells. Journal of Microbiology and Biotechnology. 2006;16(2):163-77;.

14. Rabaey K, Verstraete W. Microbial fuel cells: novel biotechnology for energy generation. TRENDS in Biotechnology. 2005;23(6):291-8;Available from: https://doi.org/10.1016/j.tibtech.2005.04.008.

15. Potter MC. Electrical effects accompanying the decomposition of organic compounds. Proceedings of the royal society of London Series b, containing papers of a biological character. 1911;84(571):260-76;Available from: https://doi.org/10. 1098/rspb.1911.0073.

16. Lewis K. Symposium on bioelectrochemistry of microorganisms. IV. Biochemical fuel cells. Bacteriological reviews. 1966;30(1):101;Available from: https://doi.org/10.1128/br.30. 1.101-113.1966.

17. Allen RM, Bennetto HP. Microbial fuel-cells. Applied biochemistry and biotechnology. 1993;39(1):27-40;Available from: https://doi.org/10.1007/BF02918975.

18. Du F, Xie B, Dong W, Jia B, Dong K, Liu H. Continuous flowing membraneless microbial fuel cells with separated elec- trode chambers. Bioresource technology. 2011;102(19):891420;Available from: https://doi.org/10.1016/j.biortech.2011.07. 056.

19. Min B, Logan BE. Continuous electricity generation from domestic wastewater and organic substrates in a flat plate microbial fuel cell. Environmental science \& technology. 2004;38(21):5809-14;Available from: https://doi.org/10.1021/ es0491026.

20. Min B, Kim J, Oh S, Regan JM, Logan BE. Electricity generation from swine wastewater using microbial fuel cells. Water research. 2005;39(20):4961-8;Available from: https://doi.org/10. 1016/j.watres.2005.09.039.

21. Yokoyama H, Ohmori H, Ishida M, Waki M, Tanaka Y. Treatment of cow-waste slurry by a microbial fuel cell and the properties of the treated slurry as a liquid manure. Animal Science Journal. 2006;77(6):634-8;Available from: https://doi.org/10.1111/j. 1740-0929.2006.00395.x.

22. Jang JK, Pham TH, Chang IS, Kang KH, Moon H, Cho KS et al. Construction and operation of a novel mediatorand membrane-less microbial fuel cell. Process biochemistry. 2004;39(8):1007-12;Available from: https://doi.org/10. 1016/S0032-9592(03)00203-6. 


\title{
Nghiên cứu khả năng xử lý tuần hoàn nước nuôi tôm bằng mô hình pin nhiên liệu sinh học không màng
}

\author{
Võ Quế Hương ${ }^{1}$, Phạm Ngọc ${ }^{2}$, Phạm Thị Hoa ${ }^{1}$
}

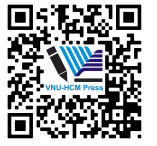

Use your smartphone to scan this QR code and download this article

\section{TÓM TẮT}

Pin nhiên liệu vi sinh (MFC), hệ thống sử dụng vi sinh vật để chuyển đổi các hợp chất hữu cơ thành năng lượng điện, là một phương pháp khả thi cao để xử lý nước thải nhiễm mặn. Hầu hết nước thải phát sinh từ nuôi trông thủy sản có chứa độ mặn cao. Ngoài ra, việc duy trì chất lượng nước tốt là điều cần thiết cho sự tăng trưởng và sống sót tối ưu của tôm. Nghiên cứu này đánh giá khả năng xử lý để tái tuần hoàn nước thải nuôi tôm và cải thiện hiệu suất tăng trưởng của Penaeus vannamei (Tôm thẻ chân trắng) của Mô hình pin nhiên liệu inh học không màng (MFCs). Sáu mô hình MFC được chế tạo bằng các vật liệu sẵn có tại địa phương như: polyvinyl clorua (PVC), bùn ky khí, điện cực dương và điện cực âm bằng lụa carbon, graphit dạng hạt, bông thủy tinh và hạt thủy tinh. Nghiên cứu này so sánh hai nghiệm thức khác nhau bao gồm: đối chứng (mô hình nuôi không có MFCs) và mô hình MFCs (mô hình ứng dụng với nuôi tôm). Mỗi nghiệm thức được thực hiện ba lần với tôm ở cỡ PL30-PL45, trọng lượng ban đầu trung bình 0,91 \pm 0 (g) và chiều dài ban đầu trung bình là $3,03 \pm 0,6(\mathrm{~cm})$. Các thí nghiệm được thiết lập bằng cách sử dụng các bể 120 $\mathrm{L}$ (thể tích làm việc $90 \mathrm{~L}$ ), đầu vào với nước biển ở độ mặn 20 ppt, nhiệt độ từ $22^{\circ} \mathrm{C}$ đến $26^{\circ} \mathrm{C}$, $\mathrm{pH}$ từ 7,5 đến 9,4 và oxy hòa tan từ 5,5 đến 7.2 . Mật độ tôm là 5 con tôm ấu trùng / lít. Kết quả nghiên cứu đạt được hiệu quả loại bỏ nhu cầu oxy hóa học, amoniac, nitrit và nitrat lần lượt lên tới 58,83\%, 76,1\%,56,33\% và 70,90\%. Tỷ lệ sống của tôm được duy trì và tốc độ tăng trưởng được cải thiện đáng kể so với xử lý đối chứng. Kết quả thu được trong nghiên cứu này cho thấy MFCs có khả năng xử lý trước tuần hoàn nước thải nuôi tôm và cải thiện năng suất tăng trưởng của Penaeus vannamei (Tôm thẻ chân trắng).

Từ khoá: Pin nhiên liệu sinh học không màng, Xử lý nước thải, Điện thế, Hệ thống tuần hoàn, Nuôi tôm, Tôm thẻ chân trắng Penaeus vannamei
${ }^{1}$ Khoa Công Nghệ Sinh Học, Trường Đai Học Quốc Tế, ĐHQG-HCM, Việt Nam

${ }^{2} B \hat{o}$ Môn Kỹ Thuật Xây Dựng, Trường Đại Học Quốc Tể, ĐHQG-HCM, Việt Nam

Lịch sử

- Ngày nhận: 25-4-2021

- Ngày chấp nhận: 14-6-2021

- Ngày đăng: 23-6-2021

DOI : $10.32508 /$ stdjsee.v5i1.556

\section{Check for updates}

\section{Bản quyền}

๑ ĐHQG Tp.HCM. Đây là bài báo công bố mở được phát hành theo các điều khoản của the Creative Commons Attribution 4.0 International license.

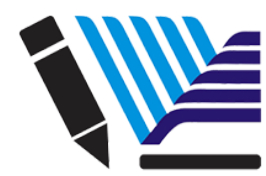

VNU-HCM Press
Trích dẫn bài báo này: Hương $V \mathrm{Q}, \mathrm{Ngọc} P, \mathrm{Hoa} P \mathrm{~T}$. Nghiên cứu khả năng xử lý tuần hoàn nước nuôi tôm bằng mô hình pin nhiên liệu sinh học không màng. Sci. Tech. Dev. J. - Sci. Earth Environ.; 5(1):336-347. 